\title{
The Study of Water Quality under Bligon Goat Rearing at Several Agroecological Zones in Bantul
}

\author{
Bambang Haryanto ${ }^{1}$, Nono Ngadiyono ${ }^{2}$, Panjono Panjono ${ }^{2}$, Siti Andarwati ${ }^{3}$, Bayu \\ Andri Atmoko ${ }^{2}$ and I Gede Suparta Budisatria ${ }^{2 *}$
}

\author{
${ }^{1}$ Graduate student of Animal Science, Faculty of Animal Science, Universitas Gadjah Mada \\ ${ }^{2}$ Department of Animal production, Faculty of Animal Science, Universitas Gadjah Mada \\ ${ }^{3}$ Department of Livestock Socio Economic, Faculty of Animal Science, Universitas Gadjah Mada \\ Corresponding author. Email: budisatria@ugm.ac.id
}

\begin{abstract}
Livestock production impacts environmental water quality related to its waste product. This research cinducted to determine water quality around the Bligon goat pen in Bantul Regency, Yogyakarta Province. Water quality measurements were conducted in upland, lowland, and coastal zones. Water was collected from 15 Bligon goat farmers' wells $(<10 \mathrm{~m}$ from the pen and $>10 \mathrm{~m}$ from other sources of contamination), which is usually consumed as drinking water. The physical quality test of water included $\mathrm{pH}$, Nitrite (NO2-N), Iron (Fe), Flouride (F), Chloride $(\mathrm{Cl})$, Hardness (CaCO3), Nitrate (NO3-N), Organic Substances (KmnO4). The biological quality test was Total coliform and e-coli. One-way ANOVA was used to analysed obtanined data. Water quality in the three agroecological zones was not different, and only $\mathrm{CaCO} 3$ content was different $(\mathrm{P}<0.05)$ between the upland, lowland, and coastal zones, $230.75 \pm 46.22 ; 191.59 \pm 53.39 ;$ and $141.29 \pm 47.78 \mathrm{mg} / \mathrm{L}$. The total coliform and e-coli levels in the upland, lowland, and coastal zones are $1600.00 \pm 0.00$ and $220.00 \pm 80.31 ; 1324.00 \pm 617.15$ and $218.00 \pm 92.03 ; 1306.00 \pm 657.40$ and $822.60 \pm 733.36 \mathrm{MPN} / 100 \mathrm{ml}$. It can be concluded that the biological quality of water around the Bligon Goat pen in Bantul Regency exceeds the standard, while the physical quality is still below the standard required by the Yogyakarta provincial government.
\end{abstract}

Keywords: Bantul regency, bligon goat, ecological, water quality, waste management

\section{INTRODUCTION}

In addition of producing meat, milk and eggs, the livestock industry also produces environmental harmful materials from its waste [1]. Along with the development of the livestock industry in developing countries, attention to livestock management waste and its associated challenges is increasing, especially in disposal [2]. Degradation of water quality concerns are in some items such as protozoan and bacterial contamination of water and soil, nutrient loses, pesticides, farm effluents in the form of livestock wastes [3].

Goat is one of livestock that's commonly kept in Indonesia. Goat is a leading commodity in the Province of the Special Region of Yogyakarta. Statistical data in 2010 and 2019 showed that the goat population in DIY increased by around $22.97 \%$, from 331,147 heads to 407,226 heads. Goat population in Bantul Regency increased by $79.80 \%$ for 9 years, with the number of
53,090 heads in 2010 increasing to 95,467 heads in 2019 [4]. The goat population in Bantul Regency is dominated by the Bligon goat breed and is found in almost all regions [5]. Bligon goat is a name for crossbreeding goats from local goats (Kacang Goats) and Etawa Crossbreed goats. Its contain $50 \%$ or higher Kacang goats blood composition and are widely distributed on the north side of Java Island and Special Province of Yogyakarta. The shape of the Bligon goat is more like the Kacang goat in exterior, namely the face profile, the shape of the ears, back, and jaw, but has a larger body size with an adult body weight range of $20-30 \mathrm{~kg}$. The characteristics of Bligon goats are slightly drooping ears, slightly convex facial profile, few tufts (long coarse hair), dense body and high meat production. Brown or red, white, black, and a combination of these three colors with fine hair all over the body [6].

Bantul Regency topographi is divided into lowlands, hilly areas and coastal areas. Most of the physiographic 
units of Bantul Regency are located on Fluvio Volcanic Plain, hills on the west and east sides and coastal physiography. Differences in topography and also type, fertility, and climatic conditions of the soli will affect livestock yields, land use management, production potential, and feed availability [7]. This research was done to provide information about water quality around the Bligon goat pen in hills, lowland, and coastal zones of Bantul Regency, Yogyakarta Province.

\section{MATERIAL AND METHODS}

\subsection{Material}

The study was conducted in 5 Kapanewon of Bantul Regency (Dlingo, Imogiri, Pajangan, Sanden and Srandakan) on April 2021. Water was collected from 15 Bligon goat farmers' wells, with less than $10 \mathrm{~m}$ distance from the pen and more than $10 \mathrm{~m}$ away from other sources of contamination). Wells where the water was collected is usually consumed as drinking water. The tools used are 2 liters capacity jar and sterile bottles with a capacity of $500 \mathrm{ml}$.

\subsection{Methods}

The physical quality test of water included $\mathrm{pH}$, Nitrate (NO3-N), Iron (Fe), Flouride (F), Chloride (Cl), Nitrite (NO2-N), Hardness (CaCO3), Organic Substances (KmnO4). The biological quality test was Total coliform and e-coli. Measurements of total E. coli (IKM/5.4.1.M/BLK-Y method) and Total coliform (IKM/5.4.1.M/BLK-Y) were carried out at the Testing and Calibration Laboratory of the Health Laboratory and
Calibration of the Special Region of Health. Yogyakarta, while the measurement of the content of iron (Fe) (SNI 6989.4-2009), fluoride (F) (SNI 06-6989.29-2005), chloride (CL) (SNI 6989.19-2009), nitrate (NO3-N) (APHA 2012, section 4500-NO3B), Nitrite (N02-N) (SNI 06-6989.9-2004), Hardness (CaCO3) (SNI 066989.12-2004), and Organic Substances (KmnO4) (SNI 06-6989.22-2004) were carried out in the installation of the Water Chemistry Physics laboratory, Center for Environmental Health Engineering and Disease Control Yogyakarta. The amount of water for each test was 100 $\mathrm{ml}$ following the existing sampling guidelines.Data were analyzed statistically with a one-way ANOVA.

\section{RESULTS AND DISCUSSION}

Bantul Regency is located between 07\%44'04"$08^{\circ} 00^{\prime} 27^{\prime \prime}$ south latitude and $110^{\circ} 12^{\prime} 34^{\prime \prime}-110^{\circ} 31^{\prime} 08^{\prime \prime}$ east longitude with $506.85 \mathrm{~km} 2$ area. Most of the physiographic units of Bantul Regency are located on alluvial plains (Fluvio Volcanic Plain), hills on the west and east sides and coastal physiography. Judging from the level of land slope, most of the Bantul Regency has a slope of $0-8 \%$ (an area of 37.4318 ha or $73.6 \%$ of the total area of Bantul Regency) which is spread in the southern, central and northern regions. The eastern and western regions generally have a slope of $8 \%$ to $40 \%$ with an area of 9,357 ha $(18.46 \%)$. A small part of the eastern and western areas covering an area of 4,009 ha (7.9\%) has a slope of more than $40 \%$. The area with the most sloping land above $40 \%$ is Kapanewon Dlingo and Imogiri, while the Kapanewon area which is dominated by flat land with a slope of less than $2 \%$ is located in Kapanewon Banguntapan, Sewon, and Sedayu, [8].

Table 1. Characteristics of Bligon goat breeders in different agroecological zones in Bantul Regency

\begin{tabular}{|l|l|l|l|}
\hline Parameter's & Hilly Zone & Lowland Zone & Coastal Zone \\
\hline Number of Breeders & 31 & 34 & 20 \\
\hline Farmer's Age & $54.42 \pm 10.2$ & $56.91 \pm 11.01$ & $53.85 \pm 11.37$ \\
\hline Farming Experience & $23.77 \pm 13.49^{\mathrm{a}}$ & $19.06 \pm 13.95^{\mathrm{ab}}$ & $13.35 \pm 8.99^{\mathrm{b}}$ \\
\hline Number of goats & $4.42 \pm 4.15^{\mathrm{a}}$ & $5.12 \pm 3.44^{\mathrm{a}}$ & $7.95 \pm 4.41^{\mathrm{b}}$ \\
\hline Pen type & & & \\
\hline \multicolumn{1}{|c|}{ Individual } & $35.71 \%$ & $56.25 \%$ & $70.00 \%$ \\
\hline \multicolumn{1}{|c|}{ Group } & $64.29 \%$ & $43.75 \%$ & $30.00 \%$ \\
\hline Waste shelter & & & $10.53 \%$ \\
\hline \multicolumn{1}{|c|}{ there is } & $8.70 \%$ & $6.25 \%$ & $89.47 \%$ \\
\hline there is not any & $91.30 \%$ & $93.75 \%$ & \\
\hline Waste treatment & & & $0.00 \%$ \\
\hline \multicolumn{1}{|c|}{ done } & $0.00 \%$ & $0.00 \%$ & $100.00 \%$ \\
\hline there is not any & $100.00 \%$ & $100.00 \%$ & $118.02 \pm 90.62$ \\
\hline Cleaning time interval (days) & $119.78 \pm 120.70$ & $93.16 \pm 63.72$ & $9.14 \pm 4.50$ \\
\hline Distance between pen and well (m) & $9.11 \pm 4.15$ & $9.10 \pm 3.85$ & \\
\hline
\end{tabular}

$a, a b, b=$ Different superscripts on the same line showed significant differences $(P<0.05)$ in the mean treatment 
Table 2. The results of water quality analysis in 3 agroecological zones of Bligon goat rearing in Bantul

\begin{tabular}{|c|c|c|c|c|c|}
\hline Contamination Type & Unit & Hilly Zone & Lowland Zone & Coastal Zone & Limit \\
\hline Coliform & MPN/100ml & $1,600.00 \pm 0.00$ & $1,324.00 \pm 617.15$ & $1,306.00 \pm 657.40$ & $1,000.00[17]$ \\
\hline e-coli & MPN/100ml & $220.00 \pm 80.31$ & $218.00 \pm 92.03$ & $822.60 \pm 733.36$ & $100.00[17]$ \\
\hline $\mathrm{pH}$ & & $7.04 \pm 0.09$ & $6.94 \pm 0.13$ & $7.04 \pm 0.18$ & $6-8.5[17]$ \\
\hline Iron (Fe) & $\mathrm{mg} / \mathrm{L}$ & $0.16 \pm 0.31$ & $0.07 \pm 0.09$ & $0.10 \pm 0.18$ & 0.30()$[17]$ \\
\hline Flouride (F) & $\mathrm{mg} / \mathrm{L}$ & $0.30 \pm 0.09$ & $0.36 \pm 0.08$ & $0.27 \pm 0.07$ & $0.50[17]$ \\
\hline chloride $(\mathrm{CL})$ & $\mathrm{mg} / \mathrm{L}$ & $21.10 \pm 6.81$ & $22.90 \pm 11.40$ & $23.00 \pm 14.17$ & $600.00[17]$ \\
\hline Nitrate $\left(\mathrm{NO}_{3}-\mathrm{N}\right)$ & $\mathrm{mg} / \mathrm{L}$ & $1.12 \pm 0.78$ & $2.13 \pm 2.57$ & $4.10 \pm 5.37$ & $10.00[17]$ \\
\hline Nitrite $\left(\mathrm{NO}^{2}-\mathrm{N}\right)$ & $\mathrm{mg} / \mathrm{L}$ & $0.01 \pm 0.00$ & $0.01 \pm 0.00$ & $0.04 \pm 0.05$ & $0.06[17]$ \\
\hline Hardness $\left(\mathrm{CaCO}_{3}\right)$ & $\mathrm{mg} / \mathrm{L}$ & $230.75 \pm 46.22^{b}$ & $191.59 \pm 53.39^{a b}$ & $141.29 \pm 47.78^{a}$ & $500.00[18]$ \\
\hline Organic Matter $\left(\mathrm{KMnO}_{4}\right)$ & $\mathrm{mg} / \mathrm{L}$ & $5.75 \pm 5.45$ & $1.64 \pm 0.88$ & $5.94 \pm 4.30$ & $10.00[18]$ \\
\hline
\end{tabular}

$a, a b, b=$ Different superscripts on the same line showed significant differences $(P<0.05)$ in the mean treatment

On the farmer experience and the number of goats parameters obtained significantly different results $(\mathrm{P}<0.05)$. Farmers with longer experience of raising livestock, tend to be open for information to change their traditional rearing patterns and overcome their difficulties [9]. The number of livestock owned by farmer influence their attitudes and decision about their livestock [10].

Majority of farmers in the three agroecological zones do not have waste storage facilities yet. There are no breeders who treat the waste produced by goats. Faeces and urine are allowed to mix and accumulate under the pen without processing at all. Water pollution caused by cow liquid waste often occurs because the liquid waste is directly discharged into the drainage channel/river without prior treatment [11]. This is in line with the statement that in the cattle fattening business, farms have not processed feces, resulting in pollution of the air, water and soil [12]. In Gunung Pati Subdistrict Central Java Province, bad water quality of the river was contributed by traditional dairy farm that dispose their waste directly to the the river [13]. E. coli and Salmonella sp. in Well water can interfere with environmental health, and is very dangerous when used for household purposes [14].

The time interval for removing goat farm waste was not significantly different in the three rearing zones. In the lowland zone, faeces and urine mixture removal is carried out after being allowed to accumulate for about 3 months, while in hills and coastal areas it is carried out for about 4 months. Farmers remove goat faeces and urine mix based on the need for fertilizer on their agriculture lands. When they need fertilizer, they will take it from the pen. Goat waste removal consideration is not based on considerations of livestock health. Indonesian farmers second reasons of keeping goats or sheep are for its manure, they use it in their paddy field and fruit trees [15].

The distance between the well and the goat pen was not significantly different in each rearing zone, in the range of $9 \mathrm{~m}$. According to recommended distance is 10 meters [14]. This condition may be due to limited land for livestock businesses owned by farmers. Farmers optimize their narrow yard of their house to raise goats. In Central Java, small ruminants' numbers are increase constantly and it can be source of pollution because they kept very close to farmers house [16].

The biological water quality around the Bligon goat rearing in Bantul Regency exceeds the standard, while the physical water quality is still below the standard required by the Government. Total coliform and e-Coli levels in the hilly, lowland and coastal zones are very high above the Water Quality Standards in the Special Region of Yogyakarta Governor Regulation NO. 20 year 2008. Maximum requirement for total Coliform content is $1000 \mathrm{MPN} / 100 \mathrm{ml}$ and for E coli it is $100 \mathrm{MPN} / 100 \mathrm{ml}$. The results were higher than the number of Coliforms and E. Coli in well water around the beef cattle herd in Kweni, Bantul, which was reported to be 93 MPN/100ml and $240 \mathrm{MPN} / 100 \mathrm{ml}$ [14]. Well water is contaminated with Co-liform because the distance between the well and the cowshouse is too close or less than 10 meters and its seeps through the water. To avoid Coliform contamination, the distance between the well and the pen must be more than 10 meters [14]. Indonesia is tropical with high temperature and humidity, so the bacteria concentrations is estimated to be high because of it [16].

Physical water quality is still below the standard required by the Government. But, it was higher in the nitrate content $(0.56 \pm 0.704 \mathrm{~m} / \mathrm{l})$ than wells water quality of the Guntur II Public Health Center working area, Demak district, but showed a better figure for iron (0.31). 
$\pm 0.32 \mathrm{mg} / \mathrm{l})$, Total hardness $(398.2 \pm 244.84 \mathrm{mg} / \mathrm{l})$, Chloride $(518.40 \pm 753.120 \mathrm{mg} / \mathrm{l})$, Nitrite $(0.65 \pm 1.006$ $\mathrm{mg} / \mathrm{l})$, Organic matter $(8.36 \pm 4.405 \mathrm{mg} / \mathrm{l})$, [19]. The results showed a high number of Nitrate $(0.68 \mathrm{mg} / \mathrm{l})$, Chloride $(11.21 \mathrm{mg} / \mathrm{l})$, Iron $(1.22 \mathrm{mg} / \mathrm{l})$, and lower hardness $(72 \mathrm{mg} / \mathrm{l})$ Nitrite $(0.02 \mathrm{mg} / \mathrm{l})$ on river water quality assessment in dairy cattle rearing in Nangkasawit village, Gunungpati sub-district, Semarang district [13]. The low nitrate and nitrite content may be due to low proportion of nitrogen in available form from the manure [16].

The water quality in the three agroecological zones was not different, only the $\mathrm{CaCO} 3$ content was different $(\mathrm{P}<0.05)$ between the hilly, lowland and coastal zones. Water hardness is a way to determine the capacity of water when it reacts with soap, the higher the water hardness value, more soap is needed to produce foam. [20]. Water hardness is generally determined by carbonate salts content that consist of calcium $(\mathrm{Ca})$ and magnesium $(\mathrm{Mg})$ ions [21]. Water hardness is influenced by geological structures, especially from the formations of the rock and the soil [22]. Manganese level of the water depends on manganese contents of the soil [16]. Sedimentary rocks with its dissolved polyvalent metal ions, soils with its seepage and runoff are the main sources of natural hardness in water [20].

\section{CONCLUSION}

Total E coli and Coliform in well water around Bligon goat rearing in Bantul is higher than the standard set by the government. While, physical water quality is still below the standard required by the government. It is important to think about the of Bligon goat waste treatment to reduce its the negative impact.

\section{AUTHORS' CONTRIBUTIONS}

IGSB and $\mathrm{BH}$ conceived and planned the study. IGSB, SA, NN and P supervised the study, BH and BAA carried out the study. IGSB, BAA and BH took the lead in writing the manuscript. All authors contributed to the study, analysis, and manuscript completion.

\section{ACKNOWLEDGMENTS}

All authors would like to say their acknowledgment to Ministry of Research and Technology/National Agency for Research and Innovation, Republic of Indonesia, for funding this study with grant no. 6/E1/KP.PTNBH/2021 and contract no. 2196/UN1/DITLIT/DIT-LIT/2021).

\section{REFERENCES}

[1] Ogbuewu I.P., V.U. Odoemenam, A.A. Omede, C.S. Durunna, O.O. Emenalom, M.C. Uchegbu, I.C. Okoli, M.U. Iloeje. 2012. Livestock waste and its impact on the environment. Scientific Journal of Review. 1(2): 17-32

[2] Akinbile C.O., Ogedengbe K. (2006): Disposal effects of animal wastes (poultry \& swine) as manure on soil fertility and growth performance of Amaranthus spp. Journal of Agricultural and Environmental Engineering Technology. 2: 1-8.

[3] Hoodaa P.S., A.C. Edwardsb, H.A. Anderson, A. Miller. 2000. A review of water quality concerns in livestock farming areas. The Science of the Total En“̈ironment. 250: 143-167.

[4] BPS Propinsi Daerah Istimewa Yogyakarta. 2020. Number of Livestock by Type and District/City in DI Yogyakarta. https://yogyakarta.bps.go.id/dynamictable/2017/0 8/02/72/jumlah-ternak-menurut-jenisnya-dankabupaten-kota-di-d-i-yogyakarta.html. Diakses tanggal: 29 Oktober 2020

[5] Rahmawati, R.D., B.A. Atmoko., I.G.S. Budisatria., N. Ngadiyono and Panjono, 2022. Exterior characteristics and body measurements of Bligon goat on the different agro-ecological zones in Bantul District, Yogyakarta, Indonesia. Biodiversitas. 23(1): 143-150. DOI. http://dx.doi.org/10.13507/biodiv/d230118

[6] Budisatria, I.G.S. dan K.A. Santosa, 2009. Germ plasm of goat in Indonesia. CV. Bawah Sadar. Yogyakarta.

[7] Kusumastuti, T.A. 2012. Kelayakan usaha ternak kambing menurut sistem pemeliharaan, bangsa, dan elevasi di Yogyakarta. Sains Peternakan. 10 (2): 75-84.

[8] Badan Perencanaan Pembangunan Daerah (BAPPEDA) Bantul.2017. Regional Profile of Bantul Regency in 2017. Pemerintah Kabupaten Bantul.

[9] Budisatria, IG.S., Panjono., N. Ngadiyono., H.M.J. Udo and B.A. Atmoko. 2021. The productivity between Bligon and Kejobong goats in Indonesia, based from on-farm and on-station research. J. anim. Health Prod. 9(3): 262-270.

[10] Haq, M.S., I.G.S. Budisatria, Panjono, and D. Maharani., 2019. Measuring the sosial economic benefits of Jabres cattle keeping in Bantarkawung sub-district, Brebes, Central Java, Indonesia. JITAA 44(2): 220-227.

[11] Bintang, Y.K., D. Chandrasasi, R. Haribowo. 2019. Study of the Effectiveness and Performance of Wastewater Treatment Plants (WTP) in Household Scale Cattle Farms. Jurnal Teknik Pengairan, 10 (1): 51-58.

[12] Muyasaroh S., 2014. Productivity of fattening beef cattle raised by farmers in the village development program (SMD) in Bantul and 
Sleman regencies. Thesis. Program Pasca Sarjana Fakultas Peternakan, Gadjah Mada University, Yogyakarta.

[13] Widiastuti E., Kustono, Adiarto and Nurliyani. 2015. The impact of the local dairy cattle farm toward the river water quality in Gunungpati Subdistrict Central Java. Internat. J. Sci. Eng. 8(1)2: 15-21.

[14] Suwito, W., Supriadi, E. Winarti, N. A. A. Tisnawati. 2014. Bacterial Pollution in Well Water Around Beef Cattle Farms in Yogyakarta. Acta Veterinaria Indonesiana. 2(2): 43-48.

[15] Udo H.M.J., H.A. Aklilu, L.T. Phong, R.H. Bosma, I.G.S. Budisatria, B.R. Patil, T. Samdup, B.O. Bebe. 2011. Impact of intensification of different types of livestock production in smallholder crop-livestock systems. Livestock Science 139: 22-29.

[16] Budisatria, I.G.S., H.M.J. Udo, A.J. van der Zijpp, T.W. Murti, E. Baliarti. 2007. Air and water qualities around small ruminant houses in Central Java-Indonesia. Small Rumin. Res. 67: 55-63.

[17] Water Quality Standards in the Province of the Special Region of Yogyakarta Pergub NO. 20 Tahun 2008

[18] Clean Water Quality Standard Regulation of the Indonesian Minister of Health: 416/MENKES/PER/IX/1990

[19] Munfiah, S., Nurjazuli, O. Setiani. 2013. Physical and Chemical Quality of Dug Well and Drilled Well Water in the Working Area of Guntur II Health Center, Demak Regency. Jurnal Kesehatan Lingkungan Indonesia. 12(2):

[20] WHO. 2010. Hardness in Drinking-water

[21] Zulfa, A., A. Rahman, F. P. Priyatna, M. R. Faadhil, R. W. Wibowo. Water Quality Testing of The Citarik River in The Conservation Area Masigit Kareumbi Park, West Java View from Chemical and Biological Aspects. Jurnal Ilmu dan Budaya. 41(72):

[22] Shakerkhatibia, M., M. Mosaferib, M. Pourakbara, M. Ahmadnejadc, N. Safavid, F. Banitorab. 2018. Comprehensive investigation of groundwater quality in the northwest of Iran: physicochemical and heavy metal analysis. Groundwater for Sustainable Development. (in press). 